\title{
The effects of cyclophosphamide alone and in combination with ascorbic acid against murine ascites Dalton's lymphoma
}

\author{
B.M. Nicol, S.B. Prasad
}

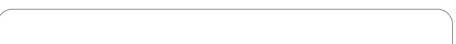

Cell and Tumor Biology Laboratory,

Department of Zoology

North-Eastern Hill University,

Shillong-793 022 India

Received: 6.7.2005

Revised: 23.3.2006

Accepted: 3.5.2006

Correspondence to:

S.B. Prasad

Email : sbpnehu@hotmail.com
\end{abstract}

\section{Introduction}

Cyclophosphamide (2-[bis-/2-chloro-ethyl-amino]tetrahydro-2H-1,2,3-oxazaphosphorine-2-oxide), is an alkylating chemotherapeutic agent with immunosuppressive activities. ${ }^{[1]}$ It is effective against a wide spectrum of malignancies, such as, leukemia, lymphoma, breast, lung, prostrate, and ovarian cancers. ${ }^{\mid 2,3]}$ The parent compound is inactive in vitro and in vivo and exerts its biologic activity through metabolites, mainly phosphoramide mustard, by hepatic microsomal enzymes. ${ }^{[4]}$ The alkylating metabolite(s) can bind to a variety of molecules including amino acids, proteins, and peptides, but the most important binding site is DNA where cross-linking occurs. ${ }^{[5]}$ Exposure of K-562 cells to 4-hydroxycyclophosphamide resulted in a concentration and time-dependent depletion of an important cellular antioxidant, reduced glutathione (GSH). It was suggested that the GSH level modulates the cytotoxic synergism between 4 -HC and cisplatin. ${ }^{[6]}$

Ascorbic acid (L,3-ketothreohexuronic acid lactone), commonly known as vitamin $\mathrm{C}$, performs antioxidative functions in vivo by serving as a hydrogen ion donor at various 
metabolic sites. It plays an important role in the metabolism and the detoxification of many endogenous and exogenous compounds. ${ }^{[7]}$ The potential role of dietary ascorbic acid to reduce the activity of free radical-induced reactions and testicular/gametogenic disorders has drawn increasing attention. ${ }^{[8]}$ The sequence-dependent synergistic antitumor effect between ascorbic acid and cisplatin against DL with much increase in host survivability has also been noted. ${ }^{[9]}$ These findings on the use of ascorbic acid with cisplatin on one side and antitumor effects of cisplatin and CP on the other generated interest to investigate the effect of ascorbic acid in combination with CP against the murine ascites Dalton's lymphoma.

Glutathione is an endogenous intracellular thiol-containing tripeptide (L- $\gamma$-glutamyl-L-cysteinyl-glycine). In mammalian cells under normal physiological conditions, more than $98 \%$ of glutathione exists in reduced form (GSH) and functions as an important cellular antioxidant. ${ }^{[10]}$ It has been the focus of interest in cancer chemotherapy. ${ }^{[1,12]} \mathrm{GSH}$ is involved directly or indirectly in a variety of biological phenomena including bioreductive reactions, maintenance of enzyme activity, amino acid transport, protection against oxidative stress, detoxification of xenobiotics, and drug metabolism. ${ }^{10]}$

The cellular carbohydrates form the important nutritional component for the cells. It has been reported by us that cisplatin treatment of DL-bearing mice caused a significant increase in carbohydrate concentration in ascites fluid and was suggested to be related to its antitumor effect on DL cells. ${ }^{[13]}$ Qualitative and quantitative changes in the cell surface carbohydrate composition, which correlate with differences in vivo behaviour accompanying malignant transformation and neoplastic progression, have been reported. ${ }^{[14]}$ This change/increase in carbohydrate in ascites fluid should not only be related with the changes in carbohydrates in tumor cells, but also other tissues of the host. With this conjecture, the determination of total carbohydrates was done in some tissues of mice in different groups. Sialic acid is an important carbohydrate constituent of cell membrane and about $70 \%$ of total sialic acid of eukaryotic cells are found on the cell surface. ${ }^{[15]}$ Therefore, sialic acid determination was also done to understand the changes in the carbohydrates, specifically at the cell surface level, in DL cells.

Considering the multifunctional significance of GSH and sialic acid/carbohydrates in cells, the present study was undertaken to elucidate the changes in these biochemical parameters in tumor cells as well as other tissues, such as, liver, kidney, and spleen of tumor-bearing mice. These changes were considered in relation to the antitumor activity of CP alone or in combination with AA. This may help to understand their possible involvement in CP-mediated antitumor effects.

\section{Materials and Methods}

\section{Chemicals}

Cyclophosphamide, reduced glutathione, 5,5'-dithiobis-2nitrobenzoic acid (DTNB), ascorbic acid, tris-[hydroxymethyl] amino-methane, ethylene-diamine tetra acetic acid (EDTA) were purchased from Sigma Chemical Co., St. Louis, MO, USA. Anthrone and other chemicals of analytical grade were bought from Sisco Research Laboratories, Mumbai, India. Doubledistilled water was always used to prepare different solutions.

\section{Tumor maintenance}

Inbred Swiss albino mice were maintained under conventional laboratory conditions. The mice were fed with commercial food pellets (Amrut Laboratories, New Delhi) and tap water ad libitum. Mice of both sexes, 10 to 12 weeks old, weighing 25 to $30 \mathrm{~g}$ were used for the experiments. Ascites Dalton's lymphoma, used in the present study, was initially obtained from Gauhati University in 1989. The tumor was maintained in vivo by serial intraperitoneal (i.p.) transplantation of $1 \times 10^{7}$ tumor cells $(0.25 \mathrm{ml}$ in phosphatebuffered saline, $\mathrm{pH}$ 7.4) per animal. Tumor-transplanted mice usually survived for 19 to 21 days.

\section{Drugs treatment schedule and antitumor activity}

The dose of CP $(200 \mathrm{mg} / \mathrm{kg})$ was selected based on the report by Czyzewska and Mazur. ${ }^{[16]}$ Tumor-transplanted mice were randomly divided into four groups, (I-IV) of 10 mice each. Group-I mice served as control and received normal saline. Group-II mice were given 1\% ascorbic acid (AA) through drinking water from the $5^{\text {th }}$ day to the $10^{\text {th }}$ day of tumor transplantation. Based on the volume of water intake (about 1.4 to $1.9 \mathrm{ml} / \mathrm{day} / \mathrm{animal}$ ), the AA intake was noted to be about $15.8-17.3 \mathrm{mg} /$ day/animal. Group-III mice were administered a single dose of CP, i.p., on the $10^{\text {th }}$ day post-tumor transplantation. Group-IV mice were given AA and, then, administered with $\mathrm{CP}$ on the $10^{\text {th }}$ day post-tumor transplantation. The survival patterns of the hosts were determined and deaths, if any, in different groups, were recorded daily.

After 24, 48, 72, and 96 h of treatment with CP (group III and IV), liver, kidneys, spleen, and tumor tissue were dissected out for biochemical investigations. The same tissues in group II were collected on the $10^{\text {th }}$ day of tumor transplantation.

The antitumor efficacy of different treatments is reported as percent increase in life span (ILS) and calculated as per the following formula:

(T/ C x 100) - 100, where $\mathrm{T}$ and $\mathrm{C}$ are the mean survival days of treated and control mice, respectively. ${ }^{[17]}$

Glutathione estimation

Total GSH (TGSH) and non-protein thiol (NPSH) content were determined using the method of Sedlak and Lindsay. ${ }^{[18]}$ Briefly, $5 \%$ homogenates of tissues were prepared in $0.02 \mathrm{~mol} /$ L EDTA, pH 4.7 in a motor-driven Teflon-pestle homogenizer. TGSH was determined by adding $100 \mathrm{ml}$ of the homogenate to $1.0 \mathrm{ml}$ of $0.2 \mathrm{~mol} / \mathrm{L}$ Tris-EDTA buffer, $\mathrm{pH} 8.2$ and $0.9 \mathrm{ml}$ of $0.02 \mathrm{~mol} / \mathrm{L}$ EDTA, pH 4.7 followed by $20 \mu \mathrm{l}$ of Ellman's reagent (10 mmol/L DTNB in methanol). For the determination of NPSH, $500 \mu \mathrm{l}$ of the homogenate was precipitated with $500 \mu \mathrm{l}$ of $10 \%$ trichloroacetic acid and centrifuged at $3000 \mathrm{x}$ g for $15 \mathrm{~min}$. To $800 \mu \mathrm{l}$ of the supernatant, $1.6 \mathrm{ml}$ of $0.4 \mathrm{~mol} / \mathrm{L}$, Tris-EDTA buffer, pH 8.9, was added before the addition of $25 \mu$ l of Ellman's reagent. After 30 min of incubation at room temperature, the reaction mixture was centrifuged and the absorbency of supernatants was read against a reagent blank at $412 \mathrm{~nm}$ using a Beckman DU-640 spectrophotometer.

As tumor-transplanted mice usually survived for 19 to 21 days, the $5^{\text {th }}, 10^{\text {th }}$, and $15^{\text {th }}$ days were considered as initial, middle, and later stages of tumor growth, respectively. Total GSH levels were also determined in DL cells on the days 5, 10, and 15 of tumor growth. 


\section{Carbohydrate and sialic acid estimation}

Estimation of carbohydrates was done by the anthrone reagent method as described by Plummer, ${ }^{[19]}$ with some modifications. Briefly, 10\% tissue homogenates were prepared in $0.6 \mathrm{~N} \mathrm{HCl}$ and were incubated in a boiling water bath for $2 \mathrm{~h}$. This was then centrifuged ( $3000 \mathrm{~g}, 10 \mathrm{~min}$ ) and the supernatant collected for the estimation. Two $\mathrm{ml}$ of the anthrone reagent was added to the samples $(1.0 \mathrm{ml})$, and the test tubes were kept in a boiling hot water bath for $10 \mathrm{~min}$ and allowed to cool at room temperature. Absorbency was measured at $620 \mathrm{~nm}$ against a reagent blank using a Beckman DU-640 spectrophotometer. Sialic acid content was estimated in the DL cells collected from mice in the experimental groups I to IV, using the method described by Warren. ${ }^{.20]}$

\section{Statistical analysis}

The significance of difference between groups was tested using one-way ANOVA followed by post-hoc Fisher's LSD test. $\mathrm{P}<0.05$ was considered significant.

\section{Results}

\section{Host survival patterns}

Following tumor transplantation, the increase in belly size and body weight, with sluggish movement of the animal was noted from the $3^{\text {rd }}-4^{\text {th }}$ day onwards depicting an early sign of tumor development. Control tumor-transplanted mice (groupI) survived for 19 to 21 days. The survival time significantly $(\mathrm{P} \leq 0.001)$ increased to 39.27 and 54.80 days with AA (groupII) and CP alone (group-III), respectively. In the group treated with $\mathrm{AA}+\mathrm{CP}$ a further significant $(\mathrm{P} \leq 0.001)$ increase in survival to 68 days was seen.[Table 1]

\section{GSH level}

Total GSH level in Dalton's lymphoma cells (group-I) increased significantly $(\mathrm{P} \leq 0.01)$ during 5 days $(3.12 \pm 0.21$ $\mu$ moles/g wet wt.) to 15 days $(4.17 \pm 0.22 \mu$ moles/g wet wt.) of tumor growth in vivo. Comparison of GSH level in the tissue
Table 1

Antitumor activity of $\mathrm{CP}$ and $\mathrm{CP}+\mathrm{AA}$ against murine ascites Dalton's lymphoma

\begin{tabular}{lccc}
\hline Treatment & Survival in days & I.L.S. (\%) \\
\hline Group-I (Control) & & $19.00 \pm 2.5$ & - \\
Group-II (AA) & & $39.25 \pm 3.2^{\mathrm{a}}$ & 106.58 \\
Group-III (CP) & & $54.80 \pm 2.8^{\mathrm{a}, \mathrm{b}}$ & 188.42 \\
Group-IV (AA + CP) & & $68.00 \pm 1.13^{\mathrm{a}, \mathrm{b}, \mathrm{c}}$ & 257.89 \\
\hline One-way & $\mathrm{F}$ & 7369.6 & \\
ANOVA & $\mathrm{df}$ & 3,36 & \\
& $P$ & $\leq 0.001$ & \\
\hline
\end{tabular}

$\mathrm{n}=10$ in each group ${ }^{\mathrm{P}} \mathrm{P}<0.001$ compared to control, ${ }^{\mathrm{b}} \mathrm{P}<0.001$ compared to groupII, ${ }^{c} P \leq 0.001$ compared to group-III. Values are expressed as the mean $\pm S D$. Control =tumourous mice without any treatment; AA = Ascorbic acid, $\mathrm{CP}=$ Cyclophosphamide.

of non-tumorous normal and tumor-bearing mice showed that the glutathione concentration did not change significantly except for an increase in spleen in the tumor-bearing mice (Group-I; Table 2). Compared with control (group-I), total GSH (TGSH) level in liver did not change significantly following CP treatment for 24 to $96 \mathrm{~h}$ (group-III), while in kidney an increase and in DL cells a decrease in the level of TGSH was noticed. [Table 2] However, CP treatment of mice (group-III), showed a significant decrease in non-protein-thiol (NPSH) concentration in the liver, kidney, and DL cells when compared with the NPSH level in respective control (group-I). The combined treatment with AA + CP (group-IV) caused more pronounced effects on the changes/decrease in both, the TGSH and NPSH concentration in liver and kidney, and NPSH level in DL cells as compared to CP alone (group-III; Table 2).

Carbohydrate and sialic acid level

A significant reduction in carbohydrate concentration in

Table 2

Total reduced glutathione (TGSH) and nonprotein glutathione (NPSH) concentration ( $\mu \mathrm{mol} / \mathrm{g}$ wet weight) in the tissues of mice under different experimental conditions

\begin{tabular}{|c|c|c|c|c|c|c|c|c|c|}
\hline \multirow{2}{*}{\multicolumn{2}{|c|}{ Treatment }} & \multicolumn{2}{|c|}{ Liver } & \multicolumn{2}{|c|}{ Kidney } & \multicolumn{2}{|c|}{ Spleen } & \multicolumn{2}{|c|}{ DL cells } \\
\hline & & TGSH & NPSH & TGSH & NPSH & TGSH & NPSH & TGSH & NPSH \\
\hline Normal & & $11.72 \pm 1.52$ & $4.20 \pm 0.80$ & $8.03 \pm 1.58$ & $2.70 \pm 0.37$ & $7.86 \pm 0.63$ & $1.82 \pm 0.47$ & - & - \\
\hline $\begin{array}{l}\text { Group-I } \\
\text { (Control) }\end{array}$ & & $11.91 \pm 0.95$ & $4.51 \pm 0.07$ & $8.50 \pm 0.92$ & $3.02 \pm 0.09$ & $9.95 \pm 0.19$ & $2.91 \pm 0.09$ & $4.63 \pm 0.16$ & $0.67 \pm 0.09$ \\
\hline $\begin{array}{l}\text { Group-II } \\
\text { (AA) }\end{array}$ & & $11.97 \pm 0.22$ & $1.15 \pm 0.06^{\mathrm{a}}$ & $9.93 \pm 0.16^{a}$ & $1.40 \pm 0.03^{\mathrm{a}}$ & $13.07 \pm 0.20^{a}$ & $2.04 \pm 0.12^{a}$ & $2.07 \pm 0.12^{\mathrm{a}}$ & $0.32 \pm 0.08^{a}$ \\
\hline $\begin{array}{l}\text { Group-III } \\
\text { (CP) }\end{array}$ & & $12.30 \pm 1.07$ & $3.11 \pm 0.54^{a, b}$ & $11.29 \pm 1.31^{a, b}$ & $2.47 \pm 0.30^{a, b}$ & $8.73 \pm 0.70^{a, b}$ & $0.87 \pm 0.29^{a, b}$ & $3.12 \pm 0.68^{a, b}$ & $0.13 \pm 0.05^{a, b}$ \\
\hline $\begin{array}{l}\text { Group-IV } \\
(A A+C P)\end{array}$ & & $9.33 \pm 1.20^{a, b, c}$ & $1.98 \pm 0.28^{a, b, c}$ & $9.56 \pm 1.45^{\mathrm{a}, \mathrm{c}}$ & $1.08 \pm 0.23^{a, b, c}$ & $8.13 \pm 0.73^{a, b, c}$ & $0.94 \pm 0.41^{a, b}$ & $2.89 \pm 0.43^{a, b}$ & $0.04 \pm 0.007^{a, b, c}$ \\
\hline One-way & $\mathrm{F}$ & 34.38 & 436.80 & 22.61 & 426.90 & 335.81 & 274.19 & 132.23 & 368.96 \\
\hline ANOVA & $d f$ & 3,20 & 3,20 & 3,20 & 3,20 & 3,20 & 3,20 & 3,20 & 3,20 \\
\hline & $p$ & 0.001 & 0.001 & 0.001 & 0.001 & 0.001 & 0.001 & 0.001 & 0.001 \\
\hline
\end{tabular}

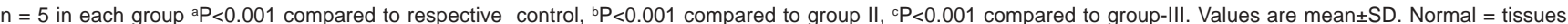

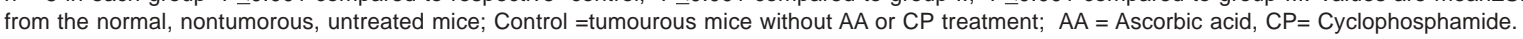


Total carbohydrate concentration ( $\mathrm{mg} / \mathrm{g}$ wet wt.) in the tissues of mice under different experimental conditions

\begin{tabular}{|c|c|c|c|c|c|}
\hline Treatment & & Liver & Kidney & Spleen & $D L$ cells \\
\hline Normal & & $8.34 \pm 0.34$ & $3.22 \pm 0.20$ & $7.90 \pm 0.35$ & - \\
\hline Group-I (Control) & & $10.12 \pm 0.24$ & $3.97 \pm 0.37$ & $9.73 \pm 0.38$ & $1.39 \pm 0.23$ \\
\hline Group-II (AA) & & $5.90 \pm 0.30^{\mathrm{a}}$ & $2.60 \pm 0.24^{a}$ & $3.20 \pm 0.15^{a}$ & $1.72 \pm 0.26^{a}$ \\
\hline Group-III (CP) & & $9.18 \pm 1.37^{b}$ & $3.09 \pm 0.66^{\mathrm{a}, \mathrm{b}}$ & $6.80 \pm 2.14^{\mathrm{a}, \mathrm{b}}$ & $1.24 \pm 0.33^{b}$ \\
\hline Group-IV (AA + CP) & & $7.48 \pm 1.33^{a, b, c}$ & $2.45 \pm 0.40^{\mathrm{a}, \mathrm{c}}$ & $5.98 \pm 1.76^{a, b}$ & $1.48 \pm 0.60^{\circ}$ \\
\hline One-way & $\mathrm{F}$ & 73.14 & 55.70 & 75.13 & 5.89 \\
\hline \multirow[t]{2}{*}{ ANOVA } & df & 3,15 & 3,15 & 3,15 & 3,15 \\
\hline & $P$ & 0.001 & 0.001 & 0.001 & 0.001 \\
\hline
\end{tabular}

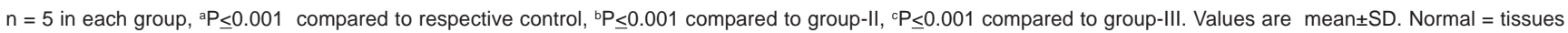

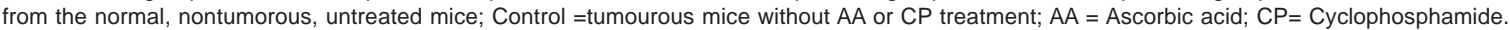

liver, kidney, and spleen of mice receiving AA (group-II) or CP treatment (group-III) was noted $(\mathrm{P} \leq 0.01)$, compared with control. Compared to the group treated with CP alone (groupIII), combination treatment (AA + CP; group-IV) caused further significant decrease of carbohydrate levels in liver and kidney, but not in spleen and DL. [Table 3] Sialic acid level decreased significantly in the groups treated with CP alone (group-III) and AA + CP (group-IV). Furthermore, compared with CP treatment alone (group-III), the combination treatment (groupIV) resulted in more pronounced decrease in sialic acid level in DL cells $(\mathrm{P} \leq 0.001$; Figure 1$)$.

\section{Discussion}

The present study reveals that CP treatment is quite effective against murine ascites Dalton's lymphoma, depicting increase in life span (I.L.S.) by about 188\% as compared with control (group-I). This substantiates its antitumor properties. CP treatment is associated with induction of oxidative stress by generation of free radicals and reactive oxygen species. ${ }^{21]}$ The potential role of dietary antioxidants, such as, ascorbic acid, tocopherol, and $\beta$-carotene to reduce the activity of free

Figure 1. Changes in sialic acid level in DL cells of mice in different experimental groups. $F=40.68, d f=3,15$ and $P \leq 0.001$. $n=5$ in each group. ${ }^{*} \mathrm{P} \leq 0.01$ when compared to control, ${ }^{\mathrm{a}} \mathrm{P} \leq 0.01$ when compared to CP. Values are mean $\pm S D$. AA- Ascorbic acid, CP-cyclophosphamide and AA plus CP.

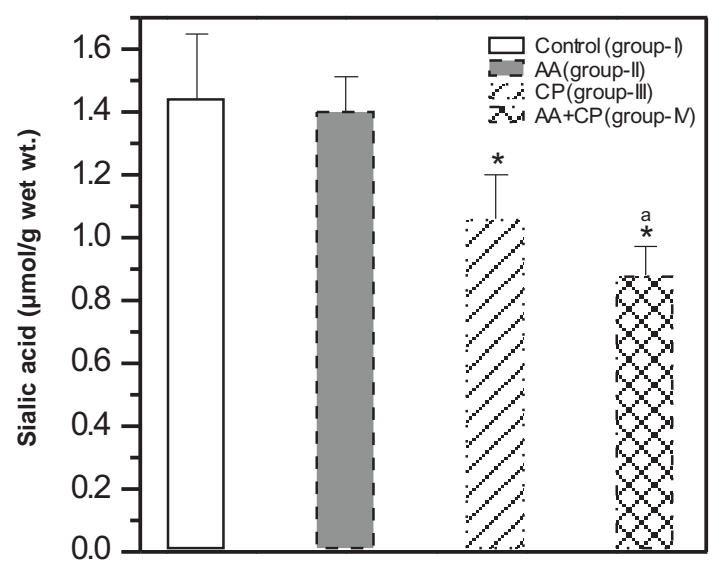

radical-induced reactions has drawn increasing attention. ${ }^{\text {[2] }}$ The reduction of dehydroascorbic acid to ascorbic acid by tissue GSH in the range of 1 to $10 \mathrm{mM}$ has been known. ${ }^{\text {[23] }}$

The study indicates a very significant increase in survival of Dalton's lymphoma tumor-bearing mice treated with AA and CP combination as compared with treatment involving either agent alone, suggesting additive/synergistic antitumor activity. This combined antitumor activity of AA and CP appears to be sequence-dependent because when mice were treated with CP first on the $10^{\text {th }}$ day and, then, AA was given for 4 to 5 days, the host survival rates were similar to the group treated with CP alone (I.L.S. 191\%). Therefore, the treatment of tumorbearing mice with $\mathrm{AA}$ first could be helpful in developing suitable conditions in the host potentiating CP's effect and more effective tumor regression. Further study is necessary to substantiate the same because present data are insufficient.

It has been reported that vitamin $\mathrm{C}$ may increase the effectiveness of CP without producing new side effects ${ }^{[24]}$ and, in fact, the AA treatment has been reported to cause a protective effect on the CP-induced testicular gametogenic and androgenic disorders. ${ }^{[8]}$ The involvement of glutathione to decrease the level of thiobarbituric acid reacting substances (TBARS) in the mice treated with CP, methotrexate, and 5fluorouracil combination has been also reported. ${ }^{[25]}$

Reduced glutathione (GSH) plays an important role in cell defense mechanisms by acting as an antioxidant or by reacting with electrophiles. It can react with many toxic agents to form conjugates that are eliminated from the cell. ${ }^{[26]}$ Determination of total GSH (TGSH) on the days 5, 10, and 15 (3.12 \pm 0.21 , $4.63 \pm 0.48$, and $4.17 \pm 0.25 \mu$ moles $/ g$ respectively) after transplantation, representing initial, middle, and later stages of tumor growth in mice (group-I) showed that the level in DL cells increased significantly. Tumor growth was maximum on day 10 and showed slight decrease thereafter over the next 4 to 5 days when tumor growth was declining. In Ehrlich ascites tumor cells, maximal GSH concentration was observed by the $7^{\text {th }}$ day, followed by a significant decrease on the $14^{\text {th }}$ day of tumor growth, which was correlated with a decrease in cell proliferation and in the rate of GSH synthesis. ${ }^{[27]}$ Cancer cells can generate large amounts of hydrogen peroxide that may contribute to their ability to damage normal tissues. ${ }^{[28]}$ The observed increase of GSH level in the DL cells with tumor 
growth may suggest its involvement in the proliferation and metabolism of tumor cells. This is in agreement with the earlier report that elevation of intracellular GSH in tumor cells is associated with mitogenic stimulation, ${ }^{[29]}$ and GSH controls the onset of tumor cell proliferation by regulating protein kinase $\mathrm{C}$ activity and intracellular $\mathrm{pH} .{ }^{[30]}$

CP alone or AA + CP treatment decreased significantly the TGSH and NPSH levels in spleen and DL cells, which may lead to alteration in the cellular antioxidant machinery to increase CP-induced cytotoxic effect on DL cells. Treatment with CP alone for 24 to $96 \mathrm{~h}$, however, did not cause much change in TGSH in liver, while it increased in the kidney.|Table 2] The protective role of ascorbic acid against cisplatin-induced mutagenic and nephrotoxic effects has also been noted with possible cooperative involvement of GSH in its protective function. ${ }^{\mid 31]}$ The intracellular NPSH also protect cells against the toxic effects of endogenous or exogenous electrophiles, such as, platinum complexes of alkylating agents. ${ }^{|32|}$ Compared with $\mathrm{CP}$ alone, the combined therapy with AA + CP caused a significant decrease in TGSH as well as NPSH in liver and kidney and TGSH in spleen. CP as such has not been reported to cause toxicity in liver or kidney, and despite a decrease in GSH, the availability of AA in combined treatment should be helpful to protect these tissues. Furthermore, the combination treatment resulted in a significant decrease in NPSH in DL cells, [Table 2] suggesting pretreatment of mice with AA enhanced the CP-mediated decrease of NPSH in DL cells. This may be one of the important factors in exhibiting better antitumor effect in combination therapy compared to CP alone. The AA exposure of tumor cells may also increase their susceptibility to lysis by DNA damaging agents. This is similar to the report that vitamin C positively modulated Mut L homologue-1 (MLH1) and p73 genes, and it improved cellular susceptibility to apoptosis triggered by the DNA-damaging agent cisplatin. ${ }^{[33]}$

The carbohydrates are an important nutritional source for the cells/tumor cells. Any changes in the carbohydrates i.e liver and kidney under different treatment conditions may help to understand the significance of nutritional involvement/ changes as a parameter in tumor regression. Compared with the control, total carbohydrate level of liver and spleen in the tumor-bearing mice was observed to be enhanced. The comparatively higher carbohydrate level in the tissues of tumor-bearing hosts may indicate higher rate of carbohydrate uptake in the tissues by the tumor-bearing mice. The tumorbearing mice receiving AA or $\mathrm{CP}$ alone showed a significant reduction in tissue carbohydrate. In DL cells, CP treatment for 24 to $96 \mathrm{~h}$ or combination treatment did not show significant change in the carbohydrate level. This may suggest that these treatments may not involve much change in carbohydrates in DL cells during tumor regression. It has been reported that an increase in carbohydrate content in DL ascites fluid during 3 to 4 days of cisplatin treatment could be due to cell mortality and that most dying cells are not able to utilise carbohydrates. ${ }^{[13]}$ Differences in the surface changes involving mucopolysaccharides may have a direct effect on cellular properties, such as, cell to cell and cell to substrate adherence, which could in turn have a direct effect on cellular behaviour in vivo. ${ }^{[15]}$

The present study revealed that treatment with CP alone or AA + CP caused a significant decrease in sialic acid content in the DL cells. Qualitative and quantitative changes in the cell surface carbohydrate composition that correlate with differences in vivo behaviour accompanying neoplastic transformation and progression have been reported. ${ }^{[15]}$ Sialic acid is an important cell membrane carbohydrate constituent and about $70 \%$ of total sialic acid of eukaryotic cells is found on the cell surface. ${ }^{|14|}$ It has been reported that with the progression of tumor development there is an increase in sialic acid content of Yoshida ascites sarcoma cells. ${ }^{[34 \mid}$ The influence of sialic acid on the oncogenicity of tumor cells may be based on (i) a negative charge determining constituent on the cell surface, resulting in loss of contact inhibition, (ii) an antigen masking agent and (iii) a component of the cell surface involved in the adherence of tumor cells to the mesothelial membrane prior to form metastasis. ${ }^{[35]}$ In the present study the sialic acid decrease with combination treatment was more marked than that of CP alone, [Figure 1] which suggests that sialic acid decrease may be playing a substantial role in the combination treatment during tumor regression. Other studies have also shown that specific release of sialic acid after neuraminidase treatment of many tumor cells, such as, Landschutz ascites tumor, L1210 tumor, and methylcholanthrene-induced fibrosarcoma resulted in increased immunogenicity and a reduced capacity of tumor cells to proliferate in vivo. ${ }^{[36]}$

Therefore, the present study shows that compared with $\mathrm{CP}$ alone, AA and CP combination treatment is more effective against murine ascites Dalton's lymphoma. The combination treatment causes pronounced change/decrease in the level of NPSH as well as sialic acid residues in tumor cells, and these biochemical changes may be important contributory steps towards tumor regression.

\section{Acknowledgment}

The authors are grateful to the UGC (under DRS support), DST (under FIST), New Delhi, and NEHU, Shillong for financial support to carry out this work. Mr. G. Rosangkima, Department of Zoology, NEHU, assisted in the preparation of the manuscript. We are thankful to Dr. Uma Shankar and Dr. Krishna Upadhaya, Botany Department, NEHU, for helping with the detailed statistical analysis.

\section{References}

1. Ahmed AR, Hombal SM. Cycophosphamide (Cytoxan). A review on relevant pharmacology and clinical uses. J Am Acad Dematol 1984;11:1115-26.

2. Moore MJ. Clinical pharmacokinetics of cyclophosphamide. Clin Pharmacokinet 1991;20:194-208.

3. Khan TS, Sundin A, Juhlin C, Wilander E, Oberg K, Eriksson B. Vincristine, cisplatin, teniposide, and cyclophosphamide combination in the treatment of recurrent or metastatic adrenocortical cancer. Med Oncol 2004;21:167-7.

4. Huang Z, Raychowdhury MK, Waxman DJ. Impact of liver P450 reductase suppression on cyclophosphamide activation, pharmacokinetics and antitumoral activity in cytochrome P450-based cancer gene therapy model. Cancer Gene Ther 2000;7:1034-42.

5. Murata M, Suzuki T, Midorikawa K, Oikawa S, Kawanishi S. Oxidative DNA damage induced by a hydroperoxide derivative of cyclophosphamide. Free Radic Biol Med 2004;37:793-802.

6. Peters RH, Jollow DJ, Stuart RK. Role of glutathione in the in vitro synergism between 4-hydroxycyclophosphamide and cisplatin in leukemia cell lines. Cancer Res 1991;51:2536-41.

7. Holloway DF, Peterson FJ. Ascorbic acid in drug metabolism. In: Roe DA, Campbell TC, editors. Drugs and nutrients. New York: Marcel Dekker; 1984.

8. Das UB, Mallick M, Debnath JM, Ghosh D. Protective effect of ascorbic acid 
on cyclophosphamide-induced testicular gametogenic and androgenic disorders in male rats. Asian J Androl 2002;4:201-7.

9. Prasad SB, Giri A, Arjun J. Use of subtherapeutical dose of cisplatin and vitamin C against murine Dalton's lymphoma . Pol J Pharmacol Pharm 1992;44: 383-91.

10. Wang W, Ballatori N. Endogenous glutathione conjugates: occurrence and biological functions. Pharmacol Rev 1998;50:335-56.

11. Arrick BA, Nathan CF. Glutathione metabolism as a determinant of therapeutic efficacy : A review. Cancer Res 1984;44:4224 -32.

12. Khynriam D, Prasad SB. Changes in endogenous tissue glutathione level in relation to murine ascites tumor growth and the anticancer activity of cisplatin. Braz J Med Biol Res 2003;36:53-63.

13. Prasad SB, Giri A. Antitumor effect of cisplatin against murine ascites Dalton's lymphoma. Indian J Exp Biol 1994;32:155-62.

14. Yogeeswaran G, Salk PL. Metastatic potential is positively correlated with cell surface sialylation of cultured murine tumor cell lines. Science 1981;212: 1514-6.

15. Warren $\mathrm{L}$. The distribution of sialic acids within the eukaryotic cell. In: Rosenberg A, Schengrund $C L$, editors. Biological roles of sialic acid. New York: Plenum Press; 1976.

16. Czyzewska A, Mazur L. Suppressing effect of WR-2721 on micronuclei induced by cyclophosphamide in mice. Teratog Carcinog Mutagen 1995;15: 10914.

17. Rosangkima G, Prasad SB. Antitumour activity of some plants from Meghalaya and Mizoram against murine ascites Dalton's lymphoma. Indian J Exp Biol 2004;42:981-8.

18. Sedlak J, Lindsay RH. Estimation of total, protein-bound and non-protein sulfhydryl groups in tissue with Ellman's reagent. Anal Biochem 1968;25: 192-205.

19. Plummer DT. Estimation of carbohydrates by the anthrone method. In: An introduction to practical biochemistry. 3rd edition. New York: Tata McGraw-Hill Publishing Company Ltd.; 1987: p. 179-80.

20. Warren L. The thiobarbituric acid assay of sialic acid. J Biol Chem 1959;234: 1971-5.

21. Manda K, Bhatia AL. Prophylactic action of melatonin against cyclophosphamide-induced oxidative stress in mice. Cell Biol Toxico 2003;19:367-72.

22. McCall MR, Frei B. Can antioxidant vitamins materially reduce oxidative damage in humans? Free Rad Biol Med 1999;26:1034-53.

23. Guaiquil VH, Farber CM, Golde DW, Vera JC. Efficient transport and accumu- lation of vitamin C in HL-60 cells depleted of glutathione. J Biol Chem 1997;272: 9915-21.

24. Taper HS, de Gerlache J, Lans M, Roberfroid M. Non-toxic potentiation of cancer chemotherapy by combined $\mathrm{C}$ and $\mathrm{K} 3$ vitamin pre-treatment. Int J Cancer 1987:40:575- 9 .

25. Muralikrishnan G, Shyamaladevi CS. The modulating effect of glutathione on lipid peroxidation in rats treated with anticancer drugs and X-ray irradiation. Indian J Pharmacol 1996;28:188-90.

26. Deleve LG, Kaplowitz N. Glutathione metabolism and its role in hepatotoxicity. Pharmacol Ther 1991;52:287-305.

27. Estrela JM, Sternandez R, Terradez P, Asensi M, Puertes IR, Vina J. Regulation of glutathione metabolism in Ehrlich ascites tumor cells. Biochem J 1992; 286:257-62.

28. Szatrowski TP, Nathan CF. Production of large amounts of hydrogen peroxide by human tumor cells. Cancer Res 1991;51:794-8.

29. Shaw JP, Chou IN. Elevation of intracellular glutathione content associated with mitogenic stimulation of quiescent fibroblasts. J Cell Physiol 1986;129: 193-8.

30. Terradez P, Asensi M, Lasso De La Vega MC, Puertes IR, Vina J, Estrela JM. Depletion of tumor Glutathione in vivo by buthionine sulfoximine: modulation by the rate of cellular proliferation and inhibition of cancer growth. Biochemical J 1993;292:477-83.

31. Giri A, Khynriam D, Prasad SB. Use of vitamin C against cisplatin induced mutagenic and nephrotoxicity . In: Sharan RN, editor. Trends in Radiation and Cancer Biology. Germany: Forschungszentrum JulichGmbh;1998.

32. Hamers FPT, Brakke JH, Cavalleti E, Tedeschi M, Marmonti L, Pezzoni G, et al. Reduced glutathione protects against cisplatin-induced neurotoxicity in rats.Cancer Res 1993;53:544- 9

33. Catani MV, Costanzo A, Savini I, Levrero M, de Laurenzi V, Wang JY, et al. Ascorbate up-regulates MLH1 (Mut L homologue-1) and p73: implications for the cellular response to DNA damage. Biochem J 2002;364:441-7.

34. Rao VS, Sirsi M. Studies on sialic acid in Yoshida ascites sarcoma cells. Indian J Biochem Biophys 1973;10:37-41.

35. Jeanloz RW, Codington JF. The biological role of sialic acid at the surface of the cell. In: Rosenberg A, Schengrund C, editors. Biological roles of sialic acid. New York: Plenum Press; 1976.

36. Bekesi JG, Roboz JP, Holland JF. Characteristics of immunity induced by neuraminidase-treated lymphosarcoma cells in $\mathrm{C}_{3} \mathrm{H}\left(\mathrm{MTV}^{+}\right)$and $\mathrm{C}_{3} \mathrm{H}(\mathrm{MTV})$ mice. Isr J Med Sci 1976;12:288-303.

\section{IPS WEBSITE \\ IPS has launched a website www.gsips.org}

Features: Online registration, Constitution and Member list at one click.

\section{Contact point:}

Dr. Prakash V. Diwan, General Secretary, IPS

E.mail: diwan@iict.res.in, diwan_prakash@rediffmail.com 